\title{
Article
}

\section{Home Gardens as a Source of Medicinal, Herbal and Food Preparations: Modern and Historical Approaches in Lithuania}

\author{
Zivile Pranskuniene $^{1,2, *(\mathbb{C})}$, Roberta Bajoraite ${ }^{2}$, Zenona Simaitiene ${ }^{3}$ and Jurga Bernatoniene ${ }^{1,2} \mathbb{C}$ \\ 1 Department of Drug Technology and Social Pharmacy, Lithuanian University of Health Sciences, \\ 44307 Kaunas, Lithuania; Jurga.Bernatoniene@1smuni.lt \\ 2 Institute of Pharmaceutical Technologies, Lithuanian University of Health Sciences, 44307 Kaunas, Lithuania; \\ roberta.bajoraite@stud.lsmu.lt \\ 3 The Museum of History of Lithuanian Medicine and Pharmacy, Rotušès 28, 01100 Kaunas, Lithuania; \\ zenona.simaitiene@1smu.lt \\ * Correspondence: zivile.pranskuniene@1smuni.lt
}

Citation: Pranskuniene, Z.;

Bajoraite, R.; Simaitiene, Z.;

Bernatoniene, J. Home Gardens as

a Source of Medicinal, Herbal and Food Preparations: Modern and Historical Approaches in Lithuania. Appl. Sci. 2021, 11, 9988. https:// doi.org/10.3390/app11219988

Academic Editor: Gregorio Peron

Received: 2 July 2021

Accepted: 22 September 2021

Published: 26 October 2021

Publisher's Note: MDPI stays neutral with regard to jurisdictional claims in published maps and institutional affiliations.

Copyright: (C) 2021 by the authors. Licensee MDPI, Basel, Switzerland. This article is an open access article distributed under the terms and conditions of the Creative Commons Attribution (CC BY) license (https:// creativecommons.org/licenses/by/ $4.0 /)$.

\begin{abstract}
The culture of home gardens in Lithuania comes from the deep traditions of agriculture. The purpose of this study was to collect and evaluate the ethnobotanical knowledge of medicinal plants grown in Taurage District home gardens and to compare it with archival sources. A field survey was conducted from July 2019 to October 2020 in the Taurage District, and the target group consisted of 27 respondents. The data obtained during the research were compared with the unpublished work of E. Šimkūnaitè, dated 1948. During the research, 100 cultivated plant species were recorded and assigned to 36 plant families (76 plant species and 38 plant families in the archival source, respectively). Many of the species grown earlier/at present in home gardens were used without EMA approved medical indications and were based solely on folk knowledge and experience in medicine. Despite the wide network of pharmacies and well-available primary health care in Lithuania, the residents of Taurage District still grow medicinal plants in their home gardens for various purposesfrom homemade medicines to food-herbal preparations. This food-medicine connection is as tight as it was in the archival study of 1948, which shows the surviving Lithuanian tradition of growing both food and medicine in home gardens. Those cultivated plants most suitable for Lithuanian climatic conditions and with ethnic heritage-based medical applications can be a source of ideas for further research.
\end{abstract}

Keywords: home gardens; herbal preparations; Lithuania

\section{Introduction}

The COVID-19 pandemic has created conditions for looking at the provision of health care via food at the household level as a crucial issue for public health, since homemade foods represent primary health care remedies that communities rely on in times of crisis [1].

It is a worldwide trend that the majority of medicinal plants sold in local markets are wild species, which is obviously an environmental issue [2], while cultivated plants solve the problem of conservation of wild plant species. In Eastern Europe, selling of crops and processed homegrown food products is closely related to the economy of these countries [3]; this trend is also observed in Lithuania, where elder people face a difficult economic situation. The cultural aspect is important too, because medicinal and food plants have long been collected or grown in Lithuania.

Often, plants from fields are planted near houses to have on hand when needed. Field plants (such as wormwood), which are necessary as a medicine and do not grow in the surrounding area, are also planted near homes. This trend is also observed in other countries, not only with medicinal plants but with wild forms of plants brought to the garden and cultivated directly for food purposes, either because of the expected greater 
harvest, instant availability or lack of presence in the region [4]. The culture of home gardens in Lithuania comes from the deep traditions of agriculture.

In Lithuania, the traditions of plant use are very old, and this is reflected in written sources from the 16th century. Jonas Bretkūnas, the son of a free Prussian and a German, who was a pastor in a Lithuanian parish on the outskirts of Karaliaučius, described Lithuanian diseases, their causes and treatment in one of his works, Postile (finished in 1589). The author noted that there are many herbalist healers in Prussia who knew how to use medicinal herbs and roots [5]. Prussia is a historical region of Europe, located southwest of Lithuania. Lithuania Minor is a historical ethnographic region of Prussia, later East Prussia in Germany, where Prussian Lithuanians or Lietuvininkai lived. Currently, its northern part is controlled by Russia (Kaliningrad Region) and Lithuania (Klaipeda Region), and the southern part belongs to Poland.

Surviving knowledge of botany and ethnobotany in Lithuania until the end of the 18th century is very scarce. The first data on Lithuanian plants of the Renaissance era can be found in the description of the Radvila Palace Garden of 1542-1547 [6]. Flora researchers, Stanislovas Bonifacas Jundzilas (1761-1847) and Jozefas Jundzilas (1794-1877), provided information about the plants of the Vilnius Region grown in flower gardens and other areas of the homestead. Jurgis Ambraziejus Pabrèža (1771-1849), a doctor and a clergyman, was one of the first botanists in Lithuania to write his botanical works in Lithuanian. He discussed the flower gardens and cultivation of other homestead plants in Samogitia and gave the dialectal names and varieties of plants in that region.

From the 15th to the 16th century, when the Valakai reform was implemented in Lithuania, peasants were given land to set-up farms. They built huts and also planted decorative trees and shrubs; the homesteads sprouted orchards and vegetable and flower gardens [7].

A characteristic feature of a traditional Lithuanian rural homestead is planting with various greenery. Knowledge of foreign plants spread through the estates among the rural people, later this connection became reversible. New specimens of Western Europe flora have been introduced and cultivated in Lithuania, enriching the local population with the knowledge found in folk medicine recipes [8]. Flowers from the garden were not for sale, they were planted for farmers' own needs, for various ceremonies and medicines [7,9]. In the second half of the 19th century, in addition to garden and orchard plants, flower gardens spread in Lithuania; in front of the house, there was always an ornate flower garden [10].

In terms of origin, plants make up the largest group of medicinal raw materials. Over 500 plants are known in folk medicine in the territory of Lithuania. One could guess that agriculture has been the main occupation of Lithuanians since ancient times. By constant interaction with plants, such as preparing the soil, fighting weeds, harvesting or looking for new useful plants, the farmer obtained a good knowledge of plants. In Lithuanian folk medicine, a great deal of attention, not any less than for therapeutic measures, was paid to the customs related to the collection and preparation of medicinal plants [11].

The collectivisation that began after the Second World War caused great damage to Lithuanian folk culture. It has contributed to the disappearance of traditional plants used in folk medicine from people's gardens and orchards [7].

Our previous study on plants cultivated in Lithuania showed that it was popular to grow medicinal plants at home, but no attention was paid to the use of those plants for food and the food-drug relationship, although such a trend was observed [12]. Archival analysis of the Lithuanian Museum of the History of Medicine and Pharmacy archives regarding plants grown in flower gardens and their use for medical and nutritional purposes has not been performed. Only part of the archival material regarding data from the PolishLithuanian-Belarusian borderland has been analysed by researchers in neighbouring countries [13].

For Lithuanian residents, the availability of pharmacies is one of the highest in the European Union. There are 47 pharmacies per 100,000 inhabitants, and this number has 
remained stable over the last decade [14]. Primary health care in this country is also well available, albeit quite expensive [15]. According to our earlier study, despite the wide choice of pharmacies from which a wide range of herbal medicines can be obtained, Lithuanians have a tendency to grow medicinal plants next to vegetables in their home gardens and to prepare their own pharmaceutical formulations for therapeutic purposes [12].

The purpose of this study was to collect and evaluate the ethnobotanical knowledge of medicinal plants grown in Taurage District home gardens and compare it with archival sources. Work-related tasks included the evaluation of the prevalence of medicinal plants grown in home gardens, their families, pharmaceutical formulations made of them and indications for their use in the research territory of Taurage District, Samogitia ethnographic region; the identification of the species of medicinal plants grown in home gardens for food and decor; the assessment of the compliance of the indications for the use of medicinal plants grown in home gardens and found during the study with European Union herbal monographs; comparing the data obtained during the study with the unpublished work of E. Šimkunaitè, dated 1948.

\section{Materials and Methods}

\subsection{Study Area}

In the territory of Lithuania, the abundant precipitation and warmth are the most important factors affecting cultivation of agricultural crops. Lithuania is in a temperate climate zone with only the Baltic coastal climate area being closer to the climate of Western Europe. According to the characteristics of Lithuanian climatic areas, Taurage borders the lower Nemunas area and the Samogitian upland as well as the central lowland area. This shows that changeable weather prevails in Tauragè. The lowest monthly average air temperature can reach $-3{ }^{\circ} \mathrm{C}$, while the average of the warmest summer month is $17-19^{\circ} \mathrm{C}$, and on the hottest days it warms up to $36^{\circ} \mathrm{C}$. Maximum annual rainfall is $60-80 \mathrm{~mm}$ [16].

The study was conducted in the Taurage District, an area in western Lithuania, Samogitia, Karšuva lowlands, on the left bank of the river Jūra. Samogitian customs and traditions prevail in the people. The district centre is named Tauragè because people used to find large auroch (tauras) horns there and named the town "auroch's horn". It was first mentioned in 1507; aurochs survived in Europe until 1627, when the last recorded auroch died in the Jaktorów Forest in Poland (this means even earlier in Lithuania). The railway and the main road Šiauliai-Tilžè go through Tauragè. There are big areas of protected forests, wetlands and Pagramantis Regional Park of river valleys and forests. The forest covers $35.19 \%$ of the district. Mostly spruce grows there, also mixed forests, birch and aspen. The valleys of the rivers Akmena and Jūra are very special, with steep slopes and terraces, plentiful outcrops, cliffs, natural meadows and wonderful forests. The forested wetlands ensure the diversity of animals and plants. Many rare species of plants, for example, Dactylorhiza fuchsii (Druce) Soó, Gladiolus imbricatus L. and Neckera pennata Hedw., grow in the Plynoji Upland [17].

Taurage and its surroundings in the 17th-18th centuries belonged to the rulers of Prussia. The Taurage estate belonged to the nobles Radvila and the owner of the estate was the King of Prussia. There was a large market square in the town with a road from there leading to Gaure and Jurbarkas. It was a great meeting place for a variety of deals and exchanges. Between the built-up road and the Jūra River were the lands of the Evangelical Lutheran and Catholic churches. In the post-war period in 1946, Taurage became a county town; later, the district centre, but only starting from 1994, the town eldership was located there. Folk medicine has always prevailed, but the local flora and folk customs have changed over the years [18].

Currently, the population of Taurage is approximately 38,000. The total area of the district is $1179 \mathrm{~km}^{2}$ of which $2.12 \%$ is occupied by towns and settlements. Through the territory of the municipality flows the Jūra River. There are 2 towns in the district, Skaudvile and Tauragè, 8 municipalities and 320 villages. Figure 1 shows the territory of Tauragè District with marked areas where structured interviews were conducted; $52 \%$ of the respondents in the survey were rural residents. 


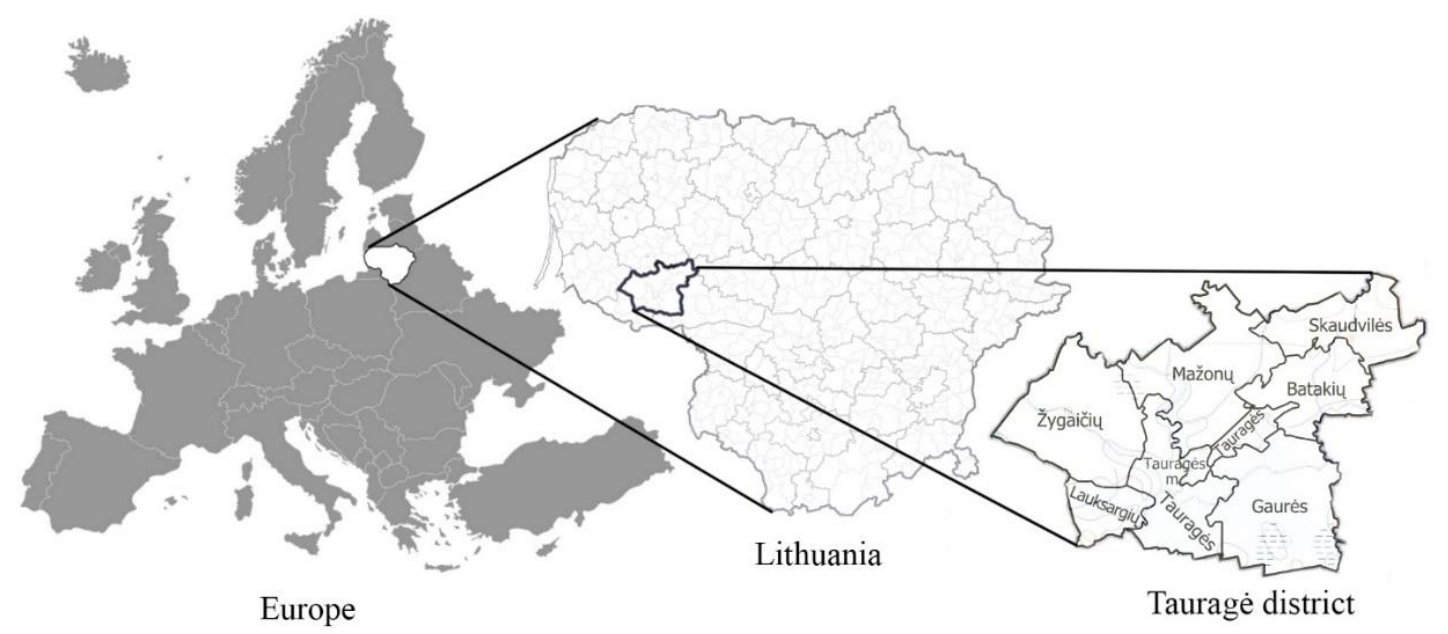

Figure 1. Study area.

\subsection{Methods}

The study was conducted from July 2019 to October 2020 in Taurage District in the territory of the Samogitia ethnographic region (Figure 1). The purpose of the study was explained to each interviewee and an informed consent form was signed prior to the interview. The study was conducted in accordance with the Code of Ethics of the International Society of Ethnobiology [19]. Interviews were recorded and coded. The research was approved by the Bioethics Center of the Lithuanian University of Health Sciences (No. BEC-FF-17). The study surveyed 30 respondents of whom 27 provided ethnobotanical material (6 men, 21 women). The maintenance of home gardens and the use of cultivated plants for food and homemade medicines, like all traditional medicine in Lithuania, has been the occupation of women $[12,20]$. At present, gardening in Lithuania is often the leisure time occupation of men of a respectable age; therefore, a larger than usual number of men were interviewed during this study. The term "home garden" is defined in this study as the entirety of naturally growing or cultivated plants grown for personal use for food and/or medicine in the area of residence.

At the beginning of the study, information was gathered about the study area, getting to know the area, people and communication culture. Permission to conduct the study was obtained from local community leaders. A study guide was chosen, who knew people and the area and who identified the members of the target group growing medicinal plants in home gardens, using them for medical purposes and food. During the research, the guide's role was performed by a resident of Tauragè, who had been engaged in herbal medicine and had excellent knowledge of folk medicine. The study group formation employed the "snowball" methodology, where one respondent recommends another member of the target group. The first meeting with the interviewed persons occurred in their home gardens. We returned to the same respondents once more to clarify the information received. The research method was a structured interview. It was carried out in two stages. During the first stage, using the prepared questionnaire, the researcher wrote down the answers to the questions. The prepared questionnaire consisted of 17 questions Questionnaire 1 (Supplementary Materials). The aim of the second stage was to gather as much information as possible about medicinal plants grown in home gardens, their purpose (for medicines, food as seasoning and decor), to identify medicinal raw materials used for medicinal purposes, their preparation methods, indications for use, doses and duration. The indications for use identified in the study were compared with European Union herbal monographs by the Committee on Herbal Medicinal Products published by the European Medicines Agency (EMA) [21]. In this way, an attempt was made to determine the extent to which the indications for use in this study matched the indications approved in the EMA studies. 
Taxonomic identification, botanical nomenclature and plant family assignment were performed based on validated databases: World Flora Online database [22] and Angiosperm Phylogeny Group IV [23]. Plant species were identified using writings on traditional Lithuanian flora [24-26].

Based on the method of comparative analysis, the data obtained during the research were compared with the unpublished work of E. Šimkūnaite, dated 1948. One of the greatest Lithuanian herbalists, E. Šimkūnaitè (1920-1996), accumulated the disappearing knowledge of folk medicine and conducted research on the rational use of medicinal plant resources and their raw materials. The most important criteria for choosing this primary archival source for comparative analysis was its well-described methodology, scientific structure and identified plant species. The research was prepared for the defence of a dissertation, but due to the unfavourable situation, it was neither defended nor published. The essence of the work was presented in the supervisor's review: "E. Šimkūnaitè with her work 'Medicinal Plants of Folk Medicine' set out to present the knowledge used in folk medicine and to evaluate it in comparison with the knowledge used in scientific medicine. Explanations of folk medicine, methods of collection, preparation, and use of folk medicinal plants, folk nomenclature for indicating their diseases, etc. are presented. The names of medicinal plants, habitats, parts used for medicinal products, preparation of the medicines, methods of administration and application are indicated. Biological effects of some medicinal plants investigated by the author herself are described. The decline of folk medicine customs and their influence due to the progress of scientific medicine has been observed" [27].

The research data are stored in the Lithuanian Museum of the History of Medicine and Pharmacy of the Lithuanian University of Health Sciences.

\section{Results and Discussion}

\subsection{Data of Taurage District Survey Respondents and Data of Archival Source}

Thirty respondents were interviewed of whom 27 (6 men and 21 women) agreed to provide data on medicinal plants grown in home gardens.

As a source of information on how and what plants to grow in the garden, $48 \%$ of respondents indicated their parents and grandparents, and $25 \%$ of respondents relied on the experiences of neighbours and other people. Only $12 \%$ looked up information in the literature (books, magazines), and 7\% used the Internet. A physician and/or a pharmacist as a source of knowledge was indicated by only $8 \%$ of respondents. The reason for this could not be the age of the respondents, as the age distribution of respondents was fairly even (Figure 2). Moreover, 63\% of respondents had a higher education, 33\% secondary, and only $4 \%$ had a basic level of education. Consequently, the choice of growing certain species in home gardens and using them for food and homemade medicines was closely linked to verbally transmitted traditions.

Data from the archival material showed that the knowledge was collected in 1925-1947. There was a total of 60 presenters of folk medicine knowledge in the work (Table 1). Group I comprised 40 presenters composed of "folk doctors, herbalists, grandmothers, whisperers who are engaged in treatment" of which 16 were men and 24 were women; Group II comprised 20 presenters who "have knowledge of folk medicine, use it for their own purposes but do not engage in treatment" of which ten were men and ten were women. The results of modern ethnobotanical research in Lithuania, as well as in this study in Taurage District, showed that the majority of presenters were women. The main reason for this is that such knowledge is traditionally passed down through the women's line, and it is not common for modern men to be interested in traditional treatment methods [12,20]. Earlier sources observed a greater focus on tradition. General knowledge was passed down to all members of the family as inheritance, but various incantations and divinations were passed down only to a person of the same sex: from father to son, from mother to daughter. In addition to transmission by inheritance, knowledge was also transmitted through teaching. An herbalist (village doctor, connoisseur) could have had several students and 
passed on general knowledge to them, but the most important knowledge and incantations would have been passed on to the most trustworthy one. This meant that not only a woman but also a man could become an herbalist (for example, there were two men presenting in this source who were "only healing").

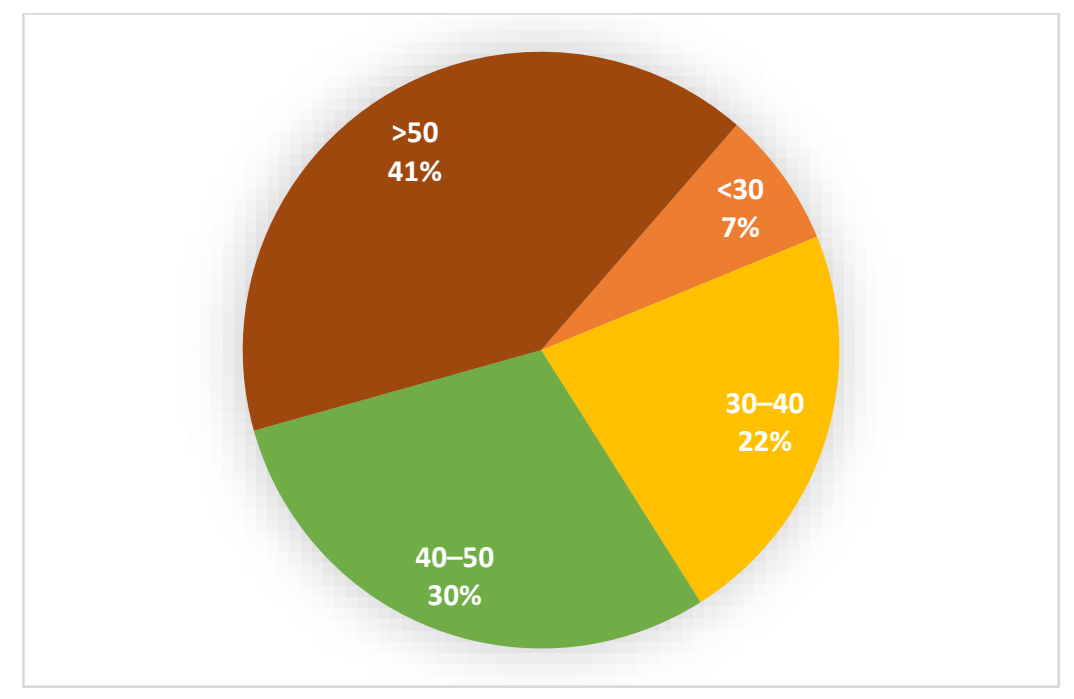

Figure 2. Percentage share of respondents by age group.

Table 1. Age of the presenters (data are presented in percentage).

\begin{tabular}{|c|c|c|c|c|}
\hline & Under 50 Years & 50-70 Years & Over 70 Years & No Data Available \\
\hline Group I (men) & & 37.50 & 56.25 & 6.35 \\
\hline Group I (women) & 8.33 & 45.83 & 37.50 & 8.33 \\
\hline & \multicolumn{2}{|c|}{ 50-70 Years } & Over 80 Years & No Data Available \\
\hline Group II (men) & \multicolumn{2}{|c|}{80.00} & 10.00 & 10.00 \\
\hline Group II (women) & \multicolumn{2}{|c|}{80.00} & 10.00 & 10.00 \\
\hline
\end{tabular}

The submitting men were peasants with the exception of two monks, one retired priest and one pharmacy garden worker. The women were peasants or housewives. By the nature of their occupations, it was not surprising that $33 \%$ of the presenters were illiterate or of poor literacy (Table 2). There was a high probability that the obtained ethnobotanical information was transmitted verbally, without the use of written sources.

Table 2. Literacy of the presenters (data are presented in percentage).

\begin{tabular}{lccccccc}
\hline Presenters & \multicolumn{2}{c}{ Illiterate } & \multicolumn{2}{c}{ Low Literacy } & \multicolumn{2}{c}{ Literate } & No Data Available \\
\hline & Men & Women & Men & Women & Men & Women & \\
\hline Group I & 7.5 & 22.5 & 7.5 & 7.5 & 22.5 & 30.0 & 2.5 \\
\hline Group II & & 5.0 & & 5.0 & 50.0 & 25.0 & 15.0 \\
\hline
\end{tabular}

All herbs reported in Tables S1 and S2 (Supplementary Materials) are designed to alleviate/treat various ailments at home but also have a different purpose such as grown/used for food as seasoning, recreational teas and simply as a decorative element at home. A large part of the species grown earlier (Table S2) and present (Table S1) in home gardens was used without EMA approved medical indications and were based solely on the folk knowledge and experience in medicine. This information can be useful for researchers to create herbal preparations according to their historical background and suitable for today's user needs. 


\subsection{Home Gardens as Sources for Medicines}

As a previous study in Lithuania on cultivated medicinal plants has shown, the primary function of home gardens is food cultivation, but all species grown there were used or consumed for medicinal purposes [12]. The study recorded 100 plant species grown for medicinal and/or nutritional purposes that belong to 36 plant families. The most common indications were gastrointestinal, respiratory diseases and also sex and urinary tract disorders (Figure 3).

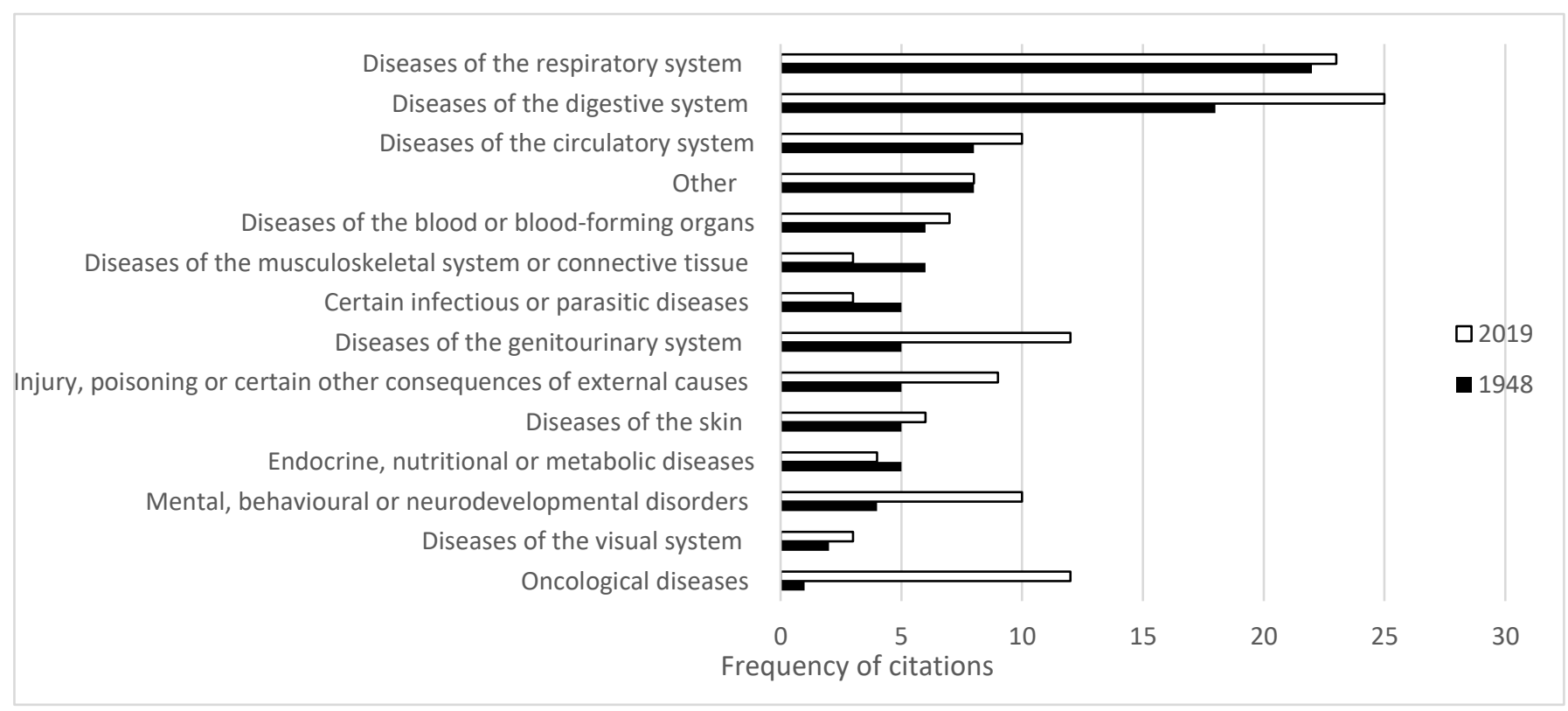

Figure 3. Indications for the use of medicinal herbal materials.

Similar results were also obtained in other studies in Lithuania $[28,29]$. It has already been discussed that these are the most common indications, possibly due to the harsh climate of Lithuania and heavy and high-caloric food consumption. Analysis of the archival data showed that the main indications were diseases of the respiratory, digestive and circulatory systems. The largest difference was observed in the treatment of oncological diseases. In the study from 1948, oncological diseases were either unknown or less prevalent, whereas today it is a common indication (9\%). Not surprisingly, as there are still many questions unanswered via science-based medicine, traditional medicine is often used to treat oncological diseases as well. Among plants used for the treatment or prevention of oncological diseases, research in Tauragè District found plants that were not typically used by Lithuanians: oregano, rosemary, tomatoes, thyme, etc. Possibly, this knowledge was obtained through written sources and mass media.

A comprehensive archival study conducted by researchers from neighbouring Latvia distinguished the use of plants for the treatment of digestive system disorders, respiratory system disorders and skin disorders. Only 59 out of 211 taxa mentioned in this study are included in the official herbal monographs of the European Medicines Agency [30]. The results of our study show that out of 100 currently used species in Taurage District and 76 plant species used for medicinal purposes in the 1948 archives, the official herbal monographs of the European Medicines Agency describe 37 (32\%) and 10 species (30\%), respectively (percentage in brackets shows an overlap of indications). Consequently, a large number of the species grown earlier/at present in home gardens were used without EMA approved medical indications and were based solely on folk knowledge and experience in medicine.

A study in neighbouring Belarus, Liuban District, recorded 45 cultivated plant taxa belonging to 27 families. The best-represented families were Lamiaceae (six taxa), Rosaceae 
(five taxa), Poaceae (four taxa), Solanaceae and Asteraceae (three taxa each) [13]. In our time, the most popular families (Lamiaceae-14, Rosaceae-12 and Asteraceae-11) were identified in Taurage District, and the archival analysis named the most popular families (Asteraceae-9, Brassicaceae-9 and Ranunculaceae-5). In Belarus, among the six most widely utilised taxa were two Allium species (garlic (A. sativum L.) and onion (A. cepa L.)), houseplant aloe (Aloe spp.), potato (Solanum tuberosum L.), aronia (Aronia spp.) and cabbage (Brassica oleracea L.) [13]. Ten of the most commonly used plants for medical purposes in the Tauragè study were dandelion (Taraxacum officinale L.), calendula (Calendula officinalis L.), thyme (Thymus vulgaris L.), raspberry (Rubus idaeus L.), mint (Mentha piperita L.), blueberry (Vaccinium myrtillus L.), wormwood (Artemisia absinthium L.), chamomile (Matricaria recutita L.) and lavender (Lavandula angustifolia L.). Marigold, chamomile, raspberry, mint and wormwood were the most commonly grown plants, very typical of Lithuanian gardens. This was also shown in a previous study in which only Tilia cordata was an exceptionally popular species [12]. J.A. Pabrèža wrote that in Samogitia, Mentha piperita in Samogitian, called Szaltmietrys, was grown in nobles' gardens, and M. crispa L., in Samogitian called Darza Mietra (garden mint), was planted in peasants' gardens [31]. Mint tea was consumed, and a large amount of mint was grown in Lithuania Minor. Mint tea was also drunk as a remedy for many diseases: indigestion (diarrhoea, abdominal pain, bloating and nausea), colds and as a sedative. It was used if anything was wrong with the eyes and for headaches [7].

Studies on food plants in Italy have shown that the highest citation rates had Taraxacum officinale (L.) Weber ex F.H. Wigg., Crepis vesicaria L., Allium cepa L. and A. sativum L. [32]. According to the frequency of citation in the Taurage District, Taraxacum officinale (L.) Weber ex F.H. Wigg. was also the most popular plant in Lithuania. It might be wrong to say this plant is "grown", because it is an unwanted weed. In our definition of "home gardens", dandelion can be classified as growing in a presenter's yard, around a garden, not weeded but, on the contrary, desired and used for treatment. Its roots are used for dandelion root coffee, which is known to improve liver function. The aboveground part is used exclusively for medicinal purposes, mainly for gallbladder and liver diseases. This is broadly in line with the indications described in the EMA monographs. As a wild food species, it was known in Poland as famine food and in Estonia as a health food. In Estonia, Taraxacum syrup (often called "dandelion honey") and wine became popular in the 1980s-1990s, and some people still make it at home [4].

In the archival analysis, due to the vague methodology, it was difficult to name the most popular plants, but according to the number of ailments, three plants with the widest range of indications could be distinguished: horseradish, Armoracia rusticana P. Gaertn; buckwheat, Fagopyrum esculentum Moench; mint, Mentha piperita L. (Table S2).

In the Taurage research, the most frequently used plant parts were leaves (158) flowers (81) and fruit (63); in the archival analysis data, flowers, leaves and roots were used 50, 47 and 33 times, respectively. The archival analysis by Latvian researchers also obtained similar results: leaves and flowers were the most commonly used parts, and herbal tea was the most common dosage form [30].

Methods of Preparation, Dosage and Methods of Administration

In the Taurage District, the main methods of preparation of raw plant materials (Figure 4) were teas (the frequency of citations was 140) prepared by just pouring hot water over and by decoctions (84) - boiling for a few minutes and simply using fresh plants without any preparation (80). The analysis of the 1948 research showed that the most popular were decoctions (98), while teas were used very rarely (9)—-medicines were prepared not just by pouring hot water over herbs, boiling for longer was required, and infusions with vodka were also popular as it meant longer shelf life, all done with fresh herbs. The consumption of a fresh plant was closely related to its use as a functional food when the medicine and the food are "two in one" and it was difficult to draw a line between them. 


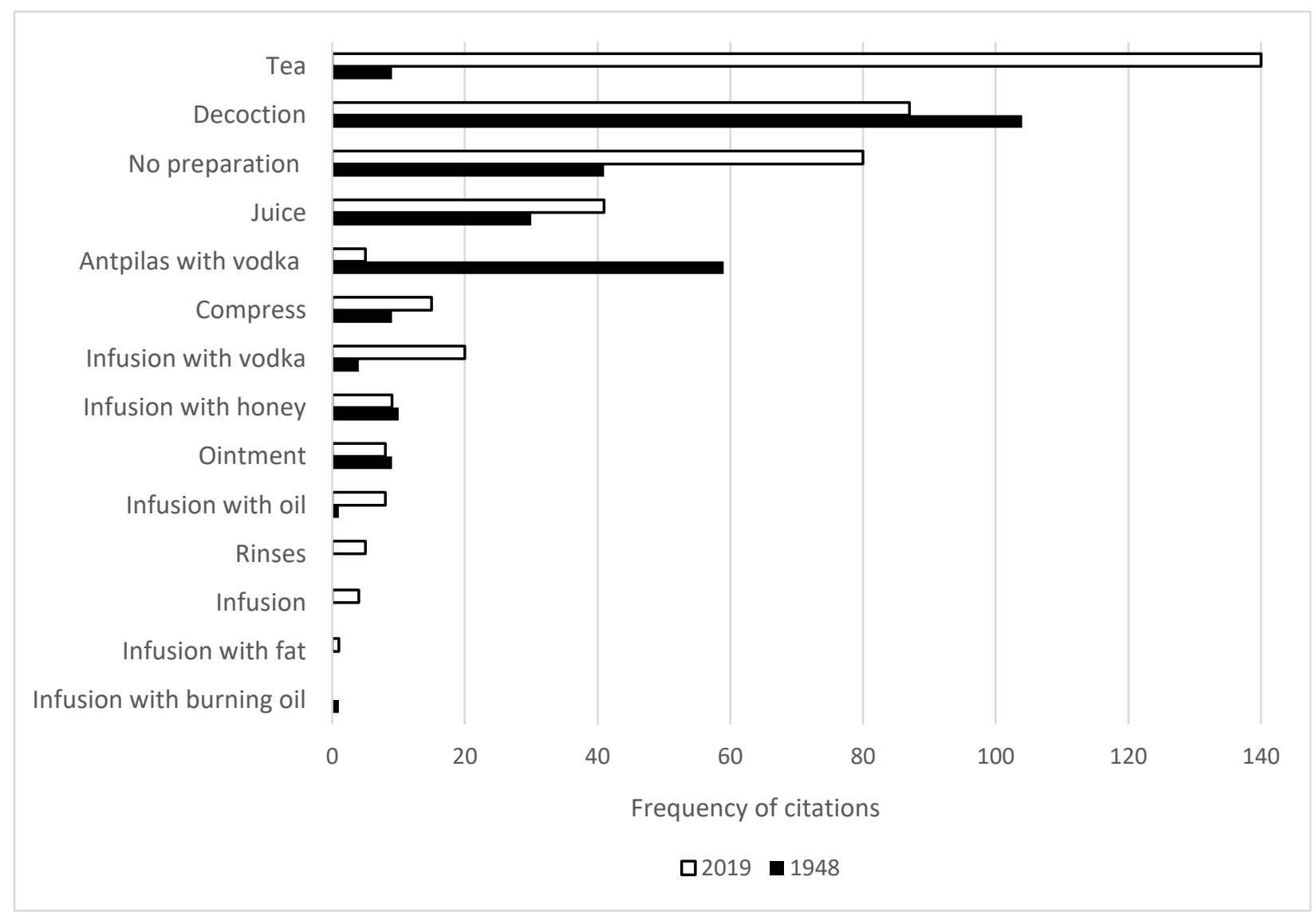

Figure 4. Preparation methods of herbal material.

With the help of information technologies, even without pharmaceutical education, it was possible to find detailed methods of the preparation of raw materials of plant origin, as well as printed publications on the same subject. Comparing the two studies, it was observed that the choice of preparation methods of medicinal plants at home among modern respondents was poorer, simplified, less attention was paid to the amounts of raw material, preparation time and other details.

Interestingly, the study in 1948 described in detail the different methods of plant preparation and even the quantities, which were measured by hand without measuring vessels.

One of the most favoured folk medicine forms, according to the 1948 study, were succus recens, juice squeezed from plants or parts of them collected just before consumption. Non-dried plants were hardly used for convenience alone, as more effort is often required to obtain a freshly cut plant than would be to have them collected and dried. It should be noted that juices were usually produced from plants harvested immediately before production, rather than cut and stored, and were usually made for a single use only. Drops had to be taken once or several times a day.

The same requirements were applied to the very popular applications of mashed succulent plants. Mashed plants are usually used externally, often smeared on a piece of clean linen canvas and left on skin overnight to be washed off in the morning with lukewarm water. A larger piece of smeared canvas than an area of unhealthy skin was applied.

Highly valued, widely consumed and not stored, all of this indicates empirical knowledge of vitamins and antibiotics. Truly, the folk persons did not know the names of vitamins and had little awareness of fast-decomposing substances, but they tried to explain the decline of action as "the life leaving it".

Aqueous extracts (sometimes using whey, sour kvass or fermented birch juice) were also made from non-dried plants. The extract was made with lukewarm or cold water from mucous or vitamin-rich plants. The extraction was carried out by grinding an equal 
volume of coarsely chopped parts of the plant and water, diluting the smooth mass to be drained, then re-grinding the residue and draining again until the required amount of liquid had been collected.

No matter how highly fresh herbs were valued, one could not stock them, neither extracts nor juices were stored. As winter approached, the herbs had to be preserved. Plants were preserved by drying, only rarely fermenting the juice. Even less often than fermentation, boiling with honey was used. Flowers and herbs were dried tied in bunches, the fruit in the sun.

The dried material was used as powder and extracts. Powder was obtained by shaving bark and roots/grinding herbs and fruit.

The powder was used per se or in a mixture with honey. A rather thin layer on the tip of bread knife or pocketknife was taken per se. It was taken by whipping with water and drinking, sprinkling on bread or folding into a small piece of bread. When mixing with honey, a mass of the proper consistency to form a pea- or hazelnut-size lump was made. The powder was to be taken once or several times a day before meals. The powder-honey mixture was prepared for the whole day.

Extracts were made with water, birch juice or kvass, homemade or state vodka, denatured alcohol, turpentine, kerosene, milk. Flowers, leaves and small grasses were not crushed, while roots, large herbs and bark were slightly crushed by breaking or rubbing between the palms.

Extracts made cold or warmed a little on the stove but not boiled are called infusions. The infusion would nearly match the official tincture. Infusions were used both internally and externally.

Denatured alcohol, turpentine, sometimes vodka, oil (from St. John's wort herb), birch juice and kvass are used for topically applied infusions. Homemade or state vodka, kvass, juice, occasionally beer, wine and mead were taken for internally used infusions.

One or more pinches of raw material were taken to prepare a half bottle of the infusion $(1 / 4 \mathrm{~L})$. The amount of raw material considered to be a pinch was easily taken with the thumb and two adjacent fingers. In the production of concentrated infusions, a bottle was filled with the raw material and as much liquid was added as needed to fill the gaps and immerse the material. Concentrated infusions were usually made from buds that had not been dried.

Nuovaras corresponds to the pharmaceutical form decoctum (decoction). The plant material was covered with cold water (sometimes over fermented kvass instead of water), placed in the wood stove with the soups and removed with them. Decoctions were drunk hot, lukewarm or cold, in sips or glasses or a fraction of it. The decoctions were not strained but pressed before drinking. For one litre or quart of decoction, a slice or handful of material was used. A handful is the amount of material that fits in one hand with all fingers folded at an angle of 120 degrees with the palm, and a double handful is the capacity of approximately two handfuls. The hands are clasped at the wrists and along the entire length of the little finger, the thumbs are closed, and the remaining fingers are clasped at the tips between the thumb and the little finger. When making decoctions from resinous substances, milk was used instead of water.

Decoctions were prepared as a single dose. For decoctions with honey and egg yolk, the drained liquid was kept in a warm place in a bowl. The yolks with honey were beaten into a homogeneous mass, gradually adding the liquid, separately cooled to 30 degrees, and mixed well; when diluted to the thickness of the cream, the whole liquid was poured and given to drink at once.

Užtvilkai, corresponding to the pharmaceutical form infusum (infusion), were usually made for one dose, taken hot. The dry substance was poured over with boiling water, brought to boil on embers, then strained or pressed. The dry-matter-to-water ratio would be the same as for a decoction. The drink was used for colds to cause sweating. Usually, 2-3 glasses were given to be drank at once, often heavily sweetened with honey or sugar. 
Teas were prepared in the same way as infusions: a few or just one pinch of herbs were added to a few litres of boiling water, brought to boil twice and then set aside (different from a modern study, where herbs were just added to boiling water). Teas were consumed like any everyday tea, hot or warm. Externally, teas were used for rinses. Tea-like diluted decoctions were made by boiling a usual decoction and diluting before consumption of one or more tablespoons of it with several times the amount of water.

Prietvilkiai, corresponding to the pharmaceutical form of poultices, were made of mucous, starchy or essential oil-rich materials (sometimes peat, clay or ash were used to make the poultices). The thickened or thick porridge was crammed into a linen bag, an old woollen sock or woollen cloth and applied to the desired place. They were not only fastened with a bandage but a much larger area was wrapped with a warm cloth.

Patches were made by boiling wax, soap, fat and gum and parts of the plant used for extraction in equal or almost equal parts. A hot patch was then strained from the herbal part. The hot or hot-blade-thawed patch was smeared on a cloth or a wilted hairy leaf and only occasionally applied immediately to a boil or area of irritation. The patches were kept for a few to several hours. If the patch was applied to a boil, then after removing it, the skin was washed and a new piece of patch applied immediately; if the patches were applied for irritation, the area was oiled after removal.

Mostys, corresponding to the pharmaceutical form unguentum (ointment), were boiled from the active ingredients and fat base. In the production of ointments from ants, live ants were instantly poured over with a hot mass of fat and immediately cooled, beaten when solid to a smooth mass. When making an ointment from balsamic shoots or needles, they were finely chopped before being poured over with fat and beaten when cool to a smooth mass. Often flour was added to the fat, followed by more or less water. Ointments were used to swell a boil, for joint pain, to "expel" various pains, for different skin diseases and inflammations, and were often rubbed in after gently beating with a silver birch leafy twigs (vanta) in a steam bath. When swelling a boil or dressing inflammations, the ointment was applied on a cloth and warmly wrapped after rubbing in the ointment.

\subsection{Home Gardens as Sources for Food}

Figure 5 shows that in the Taurage study, out of 100 recorded plant species, 49 were used for food. Respectively, in the archival data, from 76 species, 35 were used for food. All plant species recorded in the study served a medicinal purpose, but medicinal uses very often intertwined with food. For example, cultivated garlic was, indeed, used for food by each applicant, but its "superpower" indications, such as "kill tuberculosis, diphtheria bacteria" and "improve blood circulation, relieve colds", are in line with the EMA assessment Table S1 (Supplementary Materials). Preparation methods often used fresh plants, which were closely related to the plants being consumed simply as functional foods, or an infusion with vodka or honey and vinegar was made. This method of preparation was intended for longer storage and possible extraction of the active substances. The term "edible medicines", coined by Nina Etkin and adopted by other researchers [1], accurately reflects the consumption of garden plants for food which also have a healing function.

Another example could be dandelion, which was recorded in the Taurage study as the most commonly used plant for medicinal purposes. On the other hand, dandelions also have nutritional properties. It is suggested to collect dandelion early in spring, when they are just beginning to germinate, cut down to the roots and make a salad or eat about ten dandelion stems per day. To reduce the bitterness, dandelion stems should be picked together with the flowers, washed and only then should the flowers be picked. One grandmother shared her dandelion syrup recipe: washed dandelion flowers (about two full double handfuls) are slowly heated on a low heat until boiling, then placed in a cool room and left overnight. The next day, strain and add $1 \mathrm{~kg}$ of sugar or as much as you want. Heat again on a low heat to evaporate the water but not the vitamins. Neither too thick nor too liquid of a syrup must be obtained, which can then be eaten alone or smeared on bread. 


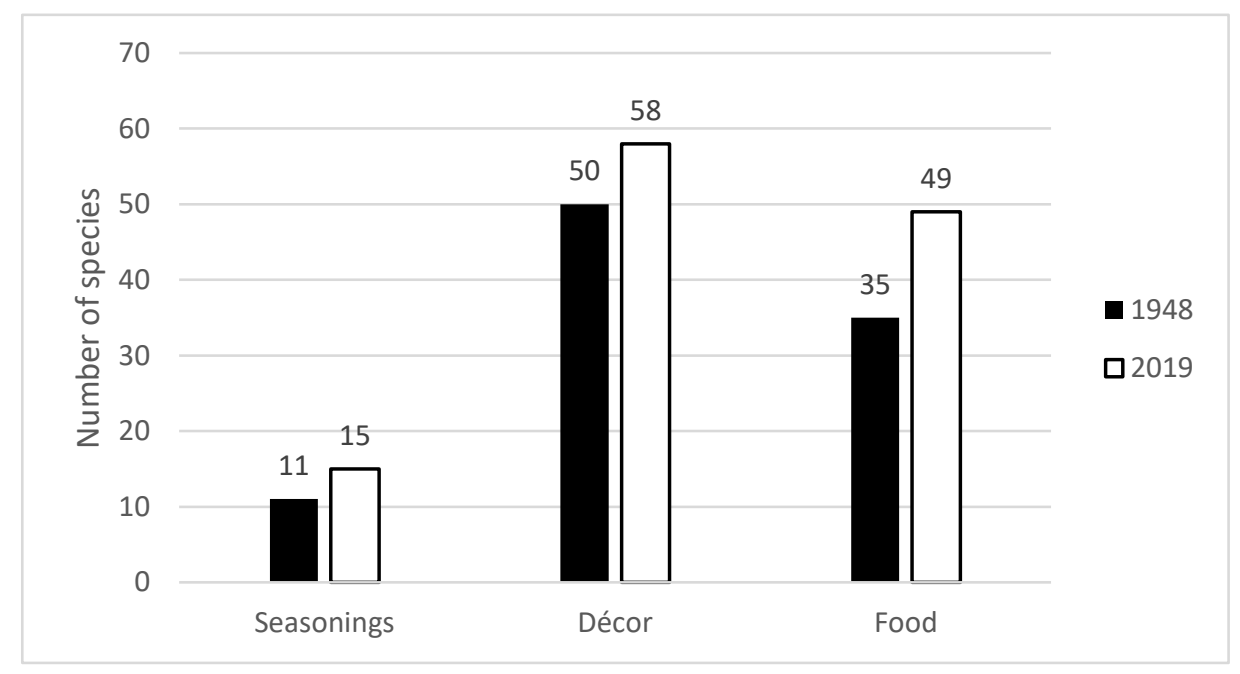

Figure 5. Other uses of herbal materials.

The COVID-19 pandemic is also changing people's attitudes towards food, creating a need to grow food for themselves. Increased seed sales have been observed in Lithuania, and homegrown food crops are, indeed, experiencing a renaissance. Information was collected during the first wave (spring 2020), which was low in Lithuania; therefore, no COVID-19 situation-related consumption was recorded. The group that was exclusively targeted were applicants abundantly and permanently growing medicinal/food plants for their own use. It was difficult to distinguish if it was only for food or only for medicine, especially if the term "for immunity, for health, to be healthy" was used.

A large-scale study was performed on homemade plant foods and beverages used during COVID-19 for preventing infection and/or treating symptoms [1]. During the study, the attitude of the Lithuanian population was also assessed. Compared to Poland and Belarus, the most diverse patterns of using food as medicine were documented in Lithuania. It was found that in pandemic news discussion forums, people mostly shared methods on how to boost the immune system. Plant-based homegrown teas, other beverages and foods "of the past" represent the initial community health response in times of uncertainty and when public health services are under pressure. They actively promoted the use of plants and honeybee products for the treatment and prevention of COVID-19 [1]. The use of honeybee products in archival sources is still widely reviewed, and these products for strengthening immunity are still popular in Lithuania [33]. Honey is used not only as a main substance but also as an excipient in the preparation of pharmaceutical forms Tables S1 and S2 (Supplementary Materials). It is suitable for sweetening medicines not only for children but also for adults, e.g., to hide the bitterness of medicinal plant raw materials. Secondly, it is a preservative that allows the prepared forms to be stored for a longer period of time [33].

The most frequently reported species during the pandemic named by Lithuanians were garlic, Allium cepa L.; nettle, Urtica dioica L.; garden nasturtium, Tropaeolum majus (L.) Kuntze. [1]. There is a tendency to use common and non-typical plants together. Our preliminary assessment showed that the pandemic has widely reinforced the relevance and use of medicinal plants and healthy foods as home remedies, even in large cities, whereby local traditions and "imported" practices based on the use of "new" plant remedies can hybridise and coexist [1]. Due to the warming climate and new knowledge, during our research in Lithuania, it was noted that plants as watermelons were grown for food and health (Figure 6). 


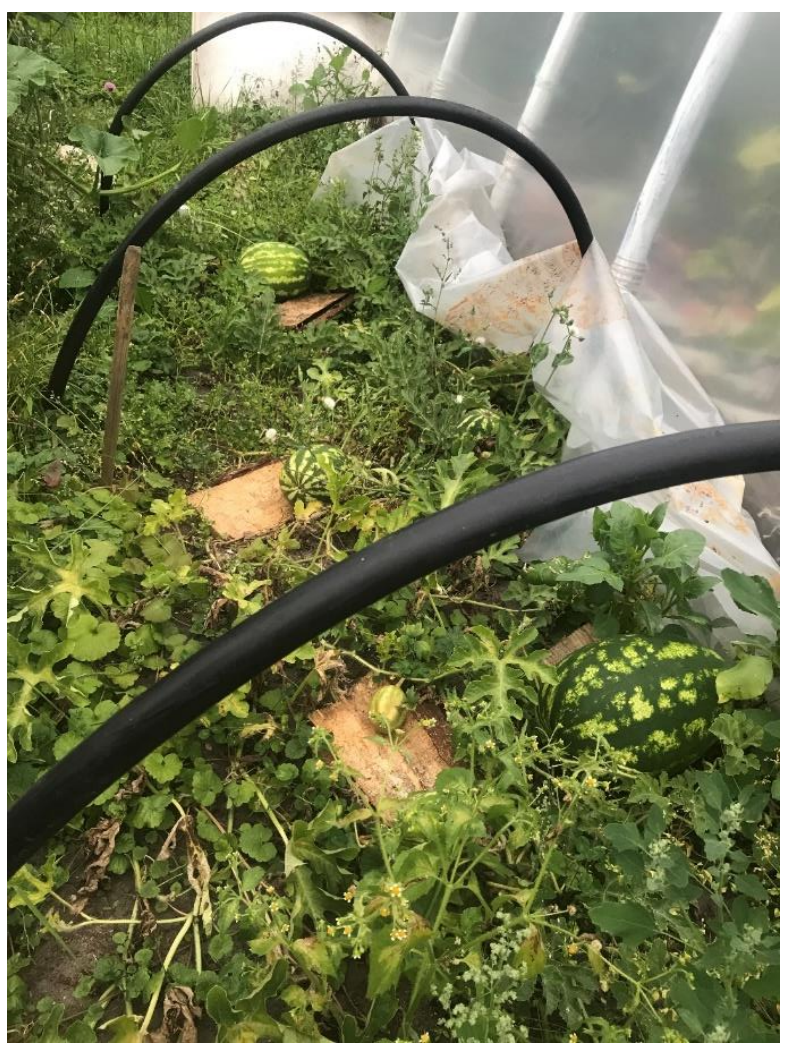

Figure 6. Watermelons in home gardens, Tauragè District.

A separate group of food-medicine can be distinguished, because it is sometimes difficult to decide. For instance, Juglans regia L. fruits are usually consumed raw before lunch or as an afternoon snack without any conscious medicinal use but are also consumed specifically to prevent high cholesterol and heart problems [34]. An example in our study could be Cannabis sativa L.- "cannabis milk, an emulsion obtained by grinding cannabis seeds with lukewarm water, is drunk for various abdominal pains; for diarrhoea, grinding into milk cannabis seed heads with almost ripe seeds". Crushed cannabis seeds are still a popular Samogitian Lenten dish, used simply as a food without any indications and with a wide range of indications if used as a remedy (Table S1).

An archival analysis of the 1948 study (Table S2) showed that the food-drug interaction as functional food was even closer. A crushed onion infusion with vodka was drunk from "old age, general weakness". Strengthening properties were attributed to beet soups, fermented and over fermented beet juices. Swede, Brassica napus L. was widely grown; its roots were chewed "to keep the teeth firm, not loose". Decoctions of flowers and seeds were drunk "from fatigue". Currently, this vegetable is not popular for growth and consumption. To improve digestion, a black mustard (Brasica nigra L.) "infusion with vodka, a pinch for a bottle, drunk by a sip or a shot glass to improve appetite" was used. As a prevention measure, mustard grains were chewed to protect against typhoid fever and cholera. Brasica oleracea L. capitata-cabbage- "stalks are given to children to chew, especially in winter and spring, to keep their teeth strong". Levisticum officinale W.D.J. Koch as dried root infusions with vodka were used "to improve digestion, prevent general weakness, prevent intestine diseases".

\subsection{Seasonings and Recreational Teas}

Fifteen and 11 plant species were grown in home gardens as a seasoning in the Tauragè study and in the 1948 study, respectively. Lithuanian cuisine was high in calories, so seasonings were necessary to improve digestion [35]. According to the 1948 data, seasonings, such as Citrus medica L., were found in archival sources: "fruit with vodka is 
drunk in fairly large quantities of 50 to $70 \mathrm{cc}$ immediately for indigestion of fatty meat foods". Armoracea rusticana Gaertn, an edible horseradish, prepared grated roots, in addition to being used as seasoning, was also used against colds, to protect against various intestine diseases, to improve digestion, for lack of appetite and for general strengthening of the body. Oregano, rosemary and basil, all of which belong to Mediterranean herbs, were also found in the Taurage research, the trend also being popular in other countries. Modern Lithuanian cuisine is lighter; therefore, the seasonings are different, but they are grown in home gardens.

The term "recreational tea", mentioned by researcher R. Soukand, describes those herbal beverages prepared as infusions that are consumed in a food context for their general social and / or recreational value or for their general attributions of being "healthy" drinks [36]. In Lithuania, there is a real tendency to use medicinal plants simply as "tea", especially if grown in one's own garden. Respondents named the reasons why: it is healthier to drink, it is grown in one's own garden and, most important, always "at hand" in the warm season and in winter it is dried. The medicinal plants singled out as recreational tea in our study were raspberry, thyme, nettle, hemp, chamomile, dandelion blossom, mint, lemon balm and quince teas. A study was conducted to assess the distribution of medicinal plant species in different regions of Europe when recreational tea is used as a refreshing drink without specific medical indications [37]. In Eastern Europe, the most popular species was red raspberry, Rubus idaeus L., and in Taurage region of Lithuania, this trend was also confirmed. According to previous studies [36,37], for recreational teas the plants often used were those which had medical applications related to climatic conditions, and the most common ailments in the region were treated with medicinal plants. This trend was also observed during this study in Lithuania. These herbs were used to relieve colds and upper respiratory tract disorders, to strengthen immunity and to treat gastrointestinal disorders (Table S1). Moreover, important sensory properties of recreational tea, such as smell, taste and colour, must be suitable for making tea. There is, of course, a debate about the long-term safety of such teas, as they are plant-based raw materials containing active substances [37].

\subsection{Decor}

Lastly, the final but not the least valuable use was home decor. During the research in Tauragè, 58 plants were included in this list, 50 were found by the archival analysis. Home decoration with trees, bushes and the spread and nurturing of home gardens became apparent in the 18th-19th centuries. The reason for decorative planting was its ornamental function [7]. In the first half of 20th century, peonies and common rue were the main flowers of the garden, elfdock (Inula helenium L.) was often grown as a medicine. The lilac, Syringa vulgaris L., was probably the most commonly grown shrub and could be found in almost every garden [31]. Polygonatum odoratum Mill was and still is a nursery plant that was grown for medicinal and cosmetic purposes; girls washed their faces with a decoction of the rhizome to make their cheeks red.

A previous study in Lithuania has found that most species of ornamental plants traditionally grown in Lithuania were used in medicine. There have been described 153 species of ornamental plants, 125 of the total number of studied plants were used for medical purposes [38]. During the study in Taurage, there was a tendency observed to grow lavender, which is not typical for Lithuanian gardens. It is still popular to plant trees near homesteads (Figures 7 and 8). 


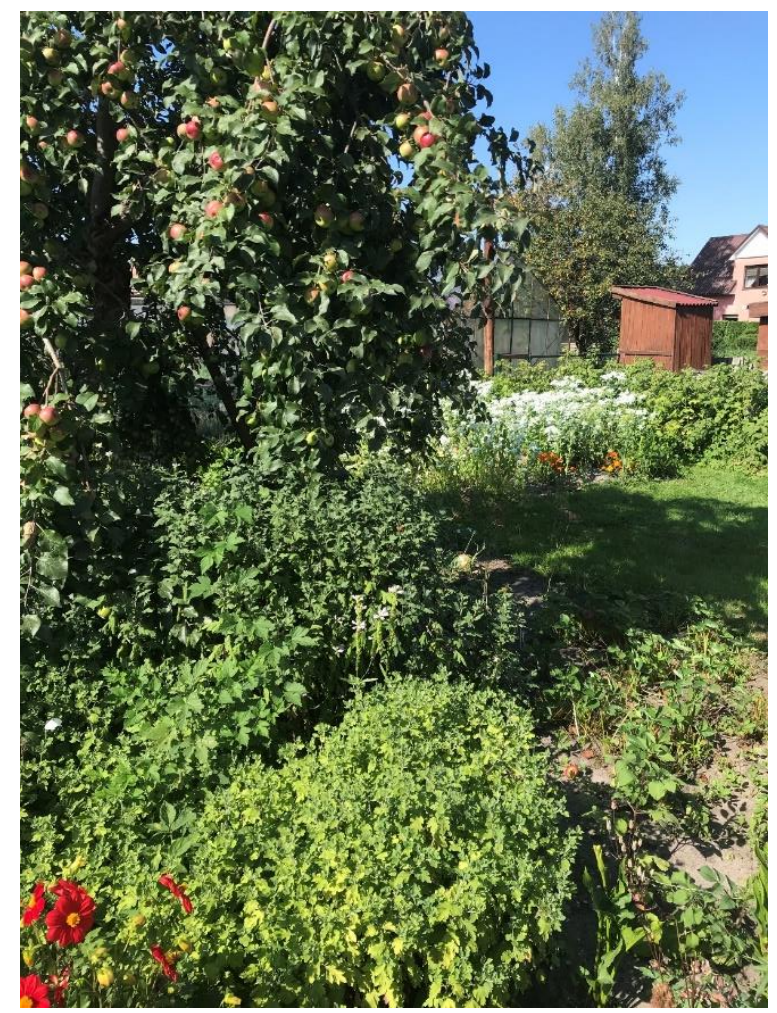

Figure 7. Home garden, Tauragè District, Lithuania.

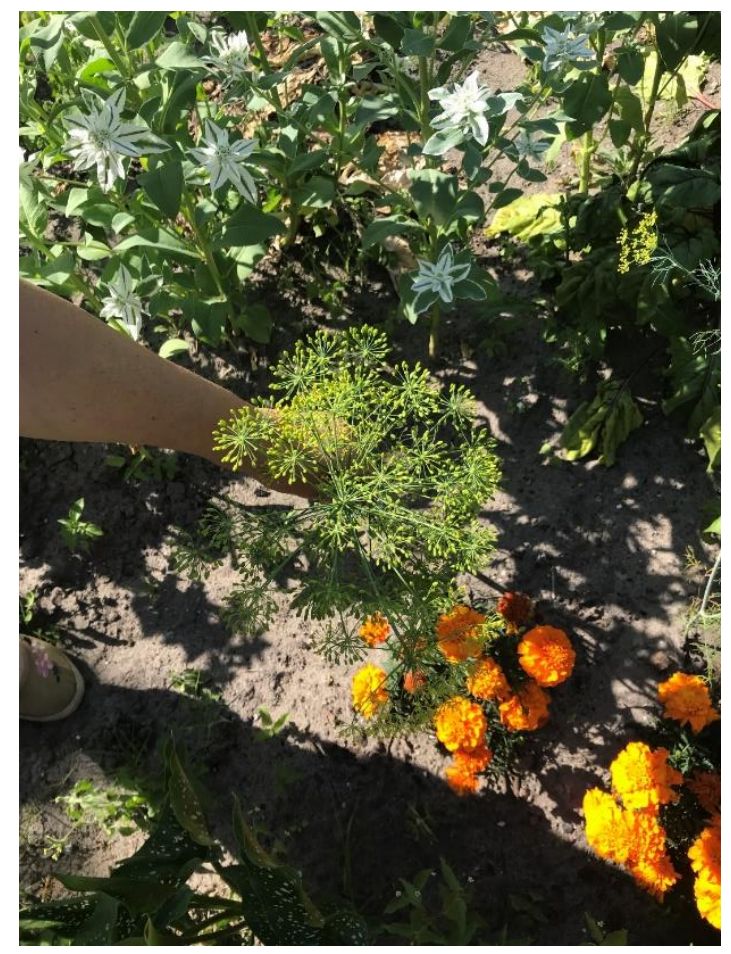

Figure 8. Home garden, Tauragè District, Lithuania, (everything together-for medicine, food and decor).

\section{Conclusions}

Despite the wide network of pharmacies and well-available primary health care in Lithuania, the residents of Taurage District still grow medicinal plants in their gardens and use them for various purposes, from homemade medicines to food-herbal preparations. 
This food-medicine interaction is as close as it was in an archival study in 1948, showing the persistent Lithuanian tradition of growing food and medicines for oneself. The global COVID-19 pandemic, as noted by ethnobotany researchers [1], forced individualisation in the home environment and the collapse of the entire health care system forced the return of forgotten knowledge of traditional medicine to have both medicine and food ready at one's fingertips. Home garden culture in Lithuania is thriving also for ecological reasons, the inherited Lithuanian agricultural tradition is nurtured, and unusual species are also being introduced due to the fact of climate change. The combination of medicinal plants traditionally grown in the Lithuanian climate and non-Lithuanian species of plants, influenced by globalisation, can be a source of ideas for creating recipes for pharmaceutical products acceptable to the modern consumer.

Supplementary Materials: The following are available online at https://www.mdpi.com/article/ 10.3390/app11219988/s1. Table S1: Herbal materials in Tauragè District home gardens; Table S2: Herbal materials in the archival source, dated 1948.

Author Contributions: Z.P. and Z.S. designed the study; Z.P. and R.B. conducted the field work; Z.S. analysis of archival sources; J.B. structured the study; Z.P. writing—original draft preparation; Z.S. and J.B. writing-review and editing; R.B. analysed the data; J.B. supervision. All authors have read and agreed to the published version of the manuscript.

Funding: This research received no external funding.

Institutional Review Board Statement: The study was conducted according to the guidelines of the Declaration of Helsinki, and approved by the Bioethics Center of the LITHUANIAN UNIVERSITY OF HEALTH SCIENCES (No. BEC-FF-17, data of approval 6 May 2019).

Informed Consent Statement: Informed consent was obtained from all subjects involved in the study.

Data Availability Statement: The data generated for this study are available from the authors upon request.

Acknowledgments: We thank all the local people who kindly shared their knowledge and lifestyle.

Conflicts of Interest: The authors declare no conflict of interest.

\section{References}

1. Pieroni, A.; Vandebroek, I.; Prakofjewa, J.; Bussmann, R.W.; Paniagua-Zambrana, N.Y.; Maroyi, A.; Torri, L.; Zocchi, D.M.; Dam, A.T.K.; Khan, S.M.; et al. Taming the pandemic? The importance of homemade plant-based foods and beverages as community responses to COVID-19. J. Ethnobiol. Ethnomed. 2020, 16, 75-79. [CrossRef] [PubMed]

2. Kasper-Pakosz, R.; Pietras, M.; Luczaj, L. Wild and native plants and mushrooms sold in the open-air markets of south-eastern Poland. J. Ethnobiol. Ethnomed. 2016, 12, 45-48. [CrossRef] [PubMed]

3. Soukand, R.; Stryamets, N.; Fontefrancesco, M.F.; Pieroni, A. The importance of tolerating interstices: Babushka markets in Ukraine and Eastern Europe and their role in maintaining local food knowledge and diversity. Heliyon 2020, 6, e03222. [CrossRef] [PubMed]

4. $\quad$ Łukasz, L.; Pieroni, P.; Javier, T.; Pardo-de-Santayana, M.; Sõukand, R.; Ingvar, S.; Raivo, K. Wild food plant use in 21st century Europe: The disappearance of old traditions and the search for new cuisines involving wild edibles. Acta Soc. Bot. Pol. 2012, 81, 359-370.

5. Ribašauskienè, E. Augalu ir ju produktų būdingu konkrečiai vietovei ar etnografiniam regionui specifikacijų nustatymas pagal papildytą tradicinių amatu klasifikacijos dali, Žolininkystè. 2014. Available online: https:/ /www.tautinispaveldas.lt/naujienos (accessed on 9 September 2020).

6. Klimienè, A.; Vainorienė, R.; Grišaitè, A. Augalu parinkimas tradiciniams gèliu darželiams šiaulių universiteto botanikos sodo pavyzdžiu. Ekonomika ir Vadyba Aktualijos ir Perspektyvos 2009, 16, 145-150.

7. Žumbakienè, G. Senieji Lietuvos Gèliu Darželiai; Lietuvos Liaudies Buities Muziejus: Kaunas, Lithuania, 2016.

8. Tschirch, A. Handbuch der Pharmakognosie; Zweite, erweiterte Abteilung: Leipzig, Germany, 1930; pp. 395-466.

9. Klimienè, A.; Vainorienè, R.; Grišaitè, A. Lietuvos Kaimo Vietoviu Konkurencingumo Stiprinimas: Geroji Patirtis; Lietuvos Kaimo plètros 2007-2013 Metu Programos Igyvendinimas; Vytauto Didžiojo Univerfsitetas: Kaunas, Lithuania, 2009.

10. Gudžinskas, Z. Tradiciniai Lietuvos Darželiu Augalai; Mokslo ir Enciklopediju Leidybos Centras: Vilnius, Lithuania, 2010.

11. Šimkūnaitè, E. Lietuviu Liaudies Medicinos Vaistingieji Augalai. 1948; Archival material. Available at Lithuanian Museum of the History of Medicine and Pharmacy of the Lithuanian University of Health Sciences. Lietuvos medicinos ir farmacijos istorijos muziejus I LSMU (lsmuni.lt). 
12. Pranskuniene, Z.; Ratkeviciute, K.; Simaitiene, Z.; Pranskunas, A.; Bernatoniene, J. Ethnobotanical Study of Cultivated Plants in Kaisiadorys District, Lithuania: Possible Trends for New Herbal Based Medicines. Evid. Based. Complement. Alternat. Med. 2019, 2019, 3940397. [CrossRef] [PubMed]

13. Soukand, R.; Hrynevich, Y.; Prakofjewa, J.; Valodzina, T.; Vasilyeva, I.; Paciupa, J.; Shrubok, A.; Hlushko, A.; Knureva, Y.; Litvinava, Y.; et al. Use of cultivated plants and non-plant remedies for human and animal home-medication in Liuban district, Belarus. J. Ethnobiol. Ethnomed. 2017, 13, 54-56. [CrossRef] [PubMed]

14. State Medicines Control Agency. Available online: http://www.vvkt.lt/Statistical-data (accessed on 10 September 2020).

15. Pranskuniene, Z.; Dauliute, R.; Pranskunas, A.; Bernatoniene, J. Ethnopharmaceutical knowledge in Samogitia region of Lithuania: Where old traditions overlap with modern medicine. J. Ethnobiol. Ethnomed. 2018, 14, 70. [CrossRef]

16. Lietuvos Hidrometeorologijos Tarnyba. Available online: http://www.meteo.lt/lt/klimatorajonavimas (accessed on 15 September 2020).

17. Taurage. Available online: https://www.vivmu.lt/wp-content/uploads/2018/08/Taurag\%C4\%97-GPP-ai\%C5\%A1kinamasisra\%C5\%A1tas.pdf (accessed on 15 September 2020).

18. Visuotine Lietuviu Enciklopedija. Available online: https://www.vle.lt/straipsnis/taurage/ (accessed on 20 September 2020).

19. International Society of Ethnobiology. International Society of Ethnobiology Code of Ethics with 2008 Additions. 2006. Available online: http:/ / ethnobiology.net/code-of-ethics / (accessed on 10 July 2019).

20. Petkevic, G. Materiaty po Narodnoj Medicine Litovcev; Zivaja Starina: Peterburg, Russia, 1911.

21. European Medicines Agency. Guideline on the Assessment of Clinical Safety and Efficacy in the Preparation of Community Herbal Monographs for Well-Established and of Community Herbal Monographs/Entries to the Community List for Traditional Herbal Medicinal Products/Substances/Preparations. 2017. Available online: https://www.ema.europa.eu/en/documents/scientificguideline/guideline-assessment-clinical-safety-efficacypreparation-eu-herbal-monographs-well-established_en.pdf (accessed on 25 September 2020).

22. WFO. 2021: World Flora Online. Available online: http://www.worldfloraonline.org (accessed on 14 September 2021).

23. Stevens, F.P. Angiosperm Phylogeny Website, Version 13. 2012. Available online: http://www.mobot.org/MOBOT/research/ APweb/ (accessed on 14 September 2021).

24. Jankevičienè, R. Botanikos Vardu Žodynas; Botanikos Instituto Leidykla: Vilnius, Lithuania, 1998.

25. Ragažinskienè, O.; Rimkienè, S.; Sasnauskas, V. Vaistiniu Augalu Enciklopedija; Lutute: Kaunas, Lithuania, 2005.

26. Vilkonis, K.K. Lietuvos Žaliasis Rübas; Lutute: Kaunas, Lithuania, 2008.

27. Grybauskas, K.; Recenzija, E. Šimkūnaitès Darbui. 1948; Archival material. Available at Lithuanian Museum of the History of Medicine and Pharmacy of the Lithuanian University of Health Sciences. Lietuvos medicinos ir farmacijos istorijos muziejus I LSMU (lsmuni.lt).

28. Mekas, T.; Petkeviciute, Z. Parallels between ethnopharmaceutic research in Wilno in 1927 and at Wornie in 2007. Analecta. Studia i Materia ły z Dziejów Nauki. 2010, 19, 83-91.

29. Petkeviciute, Z.; Savickiene, N.; Savickas, A.; Bernatoniene, J.; Simaitiene, Z.; Kalveniene, Z.; Pranskunas, A.; Lazauskas, R.; Mekas, T.A. Urban ethnobotany study in Samogitia region, Lithuania. J. Med. Plants Res. 2010, 4, 64-71. [CrossRef]

30. Sile, I.; Romane, E.; Reinsone, S.; Maurina, B.; Tirzite, D.; Dambrova, M. Medicinal plants and their uses recorded in the Archives of Latvian Folklore from the 19th century. J. Ethnopharmacol. 2020, 249, 112378. [CrossRef]

31. Pabrèža, J. Skutki lekarskie niektórych roślin i sposób używania tychże roślin w rożnych Chorobach, wyjęte z dzieła Symona Syreniusza doktor:akad. krak. przez Xiędza Jérzego Pabreża altarysty Korcianskego. roku 1814. w Korcianach. Tom II. (Some cure-specific peculiarities of the plants used invarious diseases, priests Jurgis Pabrěžos, Kartena altarists, selected from Simonas Sirenius, Doctor of Cracow Academy, 1814). Original manuscript. 1814, p. 158. Available online: http://www.epaveldas.lt/ object/recordDescription/LNB/C10000689583 (accessed on 15 September 2020).

32. Guarreraa, P.M.; Savo, V. Perceived health properties of wild and cultivated food plants in local and popular traditions of Italy: A review. J. Ethnopharmacol. 2013, 146, 659-680. [CrossRef]

33. Pranskuniene, Z.; Bernatoniene, J.; Simaitiene, Z.; Pranskunas, A.; Mekas, T. Ethnomedicinal Uses of Honeybee Products in Lithuania: The First Analysis of Archival Sources. Evid. Based Complement. Alternat. Med. 2016, 2016, 9272635. [CrossRef]

34. Alarcomicronn, R.; Pardo-de-Santayana, M.; Priestley, C.; Morales, R.; Heinrich, M. Medicinal and local food plants in the south of Alava (Basque Country, Spain). J. Ethnopharmacol. 2015, 176, 207-224. [CrossRef]

35. Dmuchovska, D.; Mickute, L. Lithuanian Cuisine. Food and Celebrations; Terra Publica: Vilnius, Lithuania, 2014.

36. Soukand, R.; Kalle, R. Where does the border lie: Locally grown plants used for making tea for recreation and/or healing, 1970s-1990s Estonia. J. Ethnopharmacol. 2013, 150, 162-174. [CrossRef]

37. Soukand, R.; Quave, C.L.; Pieroni, A.; Pardo-de-Santayana, M.; Tardio, J.; Kalle, R.; Luczaj, L.; Svanberg, I.; Kolosova, V.; Aceituno-Mata, L.; et al. Plants used for making recreational tea in Europe: A review based on specific research sites. J. Ethnobiol. Ethnomed. 2013, 9, 58. [CrossRef] [PubMed]

38. Gudelyte, U. Tradiciškai Lietuvoje Augintu Dekoratyvinių Augalu Etnofarmacinis Tyrimas. 2010. Available online: https: //www.lsmuni.lt/cris/bitstream/20.500.12512/100362/1/Tradici\%C5\%A1kai\%20Lietuvoje\%20augint\%C5\%B3\%20dekoratyvini\% C5\%B3\%20augal\%C5\%B3\%20etnofarmacinis\%20tyrimas.pdf (accessed on 28 September 2020). 